\title{
Liturgical aspects of funeral Services in Reformed Churches OF AfricAN ORIGIN
}

\author{
Author: \\ Rantoa Letsosa
}

\section{Affiliation:}

${ }^{1}$ North-West University,

School of Ecclesiastical

Studies, Practical Theology,

Faculty of Theology,

Potchefstroom,

South Africa

\section{Correspondence to:}

Rantoa Letsosa

email:

rantoa.letsosa@gmail.com

Postal address:

PO Box 20679, Noordbrug

2522, South Africa

Keywords:

Liturgy; culture; funeral service; reformed churches of African origin; burial

Dates:

Received: 24 Nov. 2009

Accepted: 03 Aug. 2010

Published: 01 Oct. 2010

How to cite this article: Letsosa, R., 2010, 'Liturgical aspects of funeral services in Reformed Churches of African origin', Verbum et Ecclesia 31(1), Art. \#361, 6 pages. DOI: 10.4102 ve.v31i1.361

\section{This article is available} at: http://www.ve.org.za
(C) 2010. The Authors. Licensee: OpenJournals Publishing. This work is licensed under the Creative Commons Attribution License.

\section{ABSTRACT}

How can the Reformed Churches of African origin arrive at a Biblical and contextual liturgy for their funeral services? Liturgy in death situations teaches people the meaning of death, and to the African, a proper funeral service or burial is a sign of respect to the deceased. Guidelines are given on how funeral services may be conducted so that they can help focus on the resurrection of the body, and the new life waiting ahead, rather than on ancestral veneration. These guidelines comprise a liturgy for mourning and funeral service, especially that at the graveside. This article is liturgical and does not intend to be dogmatic in its research.

\section{INTRODUCTION}

In the Reformed Churches of African origin ${ }^{1}$ there is almost no specific liturgy for burials. All ministers follow a certain pattern of burial or simply follow tradition, and it is clear that slight differences occur. In modern funeral services, burying people in a religious way is the option that many people still prefer. One of the basic reasons for attendance at church services is the assurance of a formal burial at death. For those who have not attended church services, a lay minister would be employed to bury the deceased.

\section{Concerning funeral services, Macleod (1966) says:}

It is a pity and shame that in two matters - weddings and funerals - the Reformed Churches have so far lost control that we ministers find ourselves officiating at what are often rather pagan ceremonies... Most funeral services bear little relation to that sense of victory which throbs on every page of the NT [New Testament] since Christ rose from the dead.

(Macleod 1966:89)

Liturgy as an act of worship and a priestly service of the believers invites us to confront the meaning of death as a profound human reality, a reality woven into the fabric of the world and its history.

The question under discussion is: How can the Reformed Churches of African origin arrive at a liturgy for the funeral service that is both Biblical and contextual? The approach used in this article comprises the basis theory, the metatheory and the praxis theory. A brief history of burials or funeral services from the Old and New Testaments is presented, as well as a short overview of the history of burial services among Christians, and the role of lamentation. The aim is to form basis-theoretical principles of liturgies for funeral services. Metatheoretical perspectives are addressed through a literature study and empirical research, followed by a set of practical guidelines for funeral services in a Reformed African context.

\section{BASIS THEORETICAL PRINCIPLES FOR FUNERAL SERVICES}

\section{Scriptural view on funeral services}

Achtemeier (ed. 1985) state that burial customs among the Hebrews consisted of two important elements: the mortuary ritual, which accompanied the burial, and the physical preparation of the body for its final resting place. Immediately after the body was prepared for burial, as a rule, the burial took place on the day of the death, as in the case of Ananias and Sapphira (Ac 5:6,10). There could be exceptions, however, as in the case of Jacob in Egypt, whose corpse had to be carried back to Canaan for proper burial.

Four stages in a typical funeral can be distinguished:

- a personal show of compassion by being present

- bewailing the dead

- removing the dead to the burial site

- the burial itself.

The personal show of compassion was considered everybody's duty in order to show solidarity. Bewailing the dead and beating the breast was very typical of a Middle Eastern funeral (Orion 1966:154).

Scripture only gives elements on how the body is prepared for burial. In Genesis $46: 4$ it is indicated that immediately after death, the eldest son of the deceased or the eldest son of a close relative would close the eyes of the deceased. The mouth of the deceased was bound shut (Jh 11:44), the body washed (Ac 9:37) and then anointed with aromatic ointments (Jh 12:7; 19:39; Mk 16:1; Lk 24:1). The body was

1.Reformed Churches of African origin refer in this context specifically to churches with only (or predominantly) non-white members, who had to adhere to the Western way of worship, irrespective of the requirements of their own culture and tradition. They had to believe that their own way of worship is sinful and therefore had to be westernised in order to be good Christians. Consequently they had to that their own way of worship is sinful and therefore had to be westernised in orde
live double lives - be Christians on Sundays and African people during the week. 
usually treated with fragrant oil (Jh 19:40) and, finally, the limbs were wrapped in a winding-sheet, with a head-cloth bound over the face (Mt 27:59; Jh 11:44). The body was wrapped in linen cloth with spices in the windings, in accordance with Jewish custom (Jh 19:40; see Jh 11:44; Ac 5:6) although individuals of high rank would frequently be clothed in fine garments ( $\mathrm{Du}$ Toit 1998:51). Jesus' anointing is described as part of his burial preparation (Mt 26:12; Mk 14:8; Jh 12:7). In the burial of Jesus, Joseph of Arimathea and Nicodemus used 'a mixture of myrrh and aloes, about a hundred pound weight' (Jh 19:39-40). The body could further be anointed even after burial, as it was the intention of the Galilean women to anoint Jesus' body (Mk 16:1; Lk 23:55-24:1).

Often a procession escorted the corpse to its resting place (Gn 50:4-14, esp. vv. 7-9). Ordinarily a coffin was not used; the body was borne on a bier (Lk 7:12 and 14) and placed directly into the tomb or grave (Achtemeier ed. 1985). In the earliest times, kinsmen carried their dead to the grave (Gn 25:9; 35:29; Jdg 16:31), but in later times, this was done by others (Am 6:10). Burial was so essential that anyone who discovered a corpse by the roadside was required to bury it (2 Sm 21:10-14). It was a great shame not to be buried. When a corpse was left to lie in the open or thrown onto a waste-dump, it was known as an 'ass's funeral'.

Du Toit (1998:53) states that cemeteries were normally outside a city or town. Individual or family crypts with more than one room were used. If the grave became too full, the bones were often placed in stone coffins (ossuaries). There were also communal graves (Mt 27:7). Poorer people buried their dead in graves dug in the earth, and covered them with stones (Orion 1996:135). Only leaders were allowed to be buried within the city walls (1 Kg 2:10; see also Actemeier 1985). The tombs of the wealthy were frequently located in gardens $(2 \mathrm{Kg} 21: 18,26$; Mt 27:57; Jh 19:41-42). Some tombs were marked by monuments or pillars, or were whitewashed on the outside ( $2 \mathrm{Kg} 23: 17$; Mt 23:27) to prevent Jews from accidentally touching them and being rendered ceremonially defiled. According to Achtemeier (ed. 1985) both archaeological and biblical data indicate that individuals of wealth or political rank enjoyed burials with elaborate funerary assemblages that included robes, jewellery, furniture, weapons and pottery (1 Sm 28:14; Is 14:11; Ez 32:27) Graves built from dressed stone were commissioned by some, while others had graves carved out of rock (Lk 23:53; Jh 19:41; Mk 5:3). As a precaution against wild animals and robbers, the grave could be closed with a hinged door and locked, or else the mouth of the grave was covered with a great circular stone, which could be rolled back and forth (see Mt 27:60; Mk 16:3-4; see also Easton [1897] 1996). After the burial, a funeral meal was usually served (2 Sm 3:35; Jr 16:5, 7; Hs 9:4).

\section{Scriptural concept of mourning}

Christian burial was viewed in the light of the hope of resurrection. Death was referred to as sleep (1 Th 4:13) and the grave as a place of rest. The body was viewed with respect as the Temple of the Holy Spirit (1 Cor 6:19) and as the subject of resurrection (1 Cor 6:13-14). The use of professional mourners was quite common when finances permitted it (Mk 5:38). However, pagan excess in mourning was discouraged (1 Th 4:13). Christians could cry for the immediate loss, yet they should at the same time also have thought of the heavenly joy and the glory that would be waiting in the New Jerusalem. Jesus conquered death and so should all those who believe in him have victory over it. Burial was also used symbolically to depict the believer's positional identification with Christ in death to $\sin (\mathrm{Rm}$ 6:4-5; see also Pfeiffer 1975).

The procession was led by such professional mourners and, at times, flautists, followed by family members who filled the air with cries of sadness and agony (Am 5:16; Ec 12:5; Job 21:33; Jer 9:17; Mt 9:23; 2 Sm 3:31; 2 Sm 3:32;). The period of mourning varied among the ancient Hebrews. Mourning for Jacob lasted for 70 days (but this also included the embalming period; Gn 50:3) while Aaron (Nm 20:29) and Moses (Dt 34:5-8) were mourned for a period of 30 days after burial. The Talmud also has a number of restrictions with regard to the mourning:

He (the bereaved) is forbidden to do work, to bathe, or anoint himself, to have (marital) intercourse; he is forbidden to read the Pentateuch, Prophets, or Hagiography, or to recite the Mishnah, or Midrash and halacoth, or the Talmud or aggadot.

(Rowell 1977:3)

\section{The church historical concept of funerals and mourning}

White (1990:288) states clearly that information about Christian burial in the first three centuries $\mathrm{AD}$ is very scarce. The general atmosphere of Christian burials was one of hope in the resurrection. Dead Christians who had kept the faith were treated as victors, and the funeral processions had the character of the triumphal processions accorded victorious generals upon their return home. Bodies were washed, anointed and wrapped in linen at the home of the deceased while prayers were said (Forrester, McDonald \& Tellini 1983:158-159; White 1990:288) Due to the fact that cemeteries were outside the city walls, the procession with the body was a significant part of the rite. It was accompanied by psalms of hope, praises and shouts of 'hallelujah'. White garments were worn by the dead as well as the family, palm leaves and lights were carried and incense was burned as the community marched to the cemetery in broad daylight (unlike the night-time funerals of pagans). At the graveside service, there was prayer and a celebration of the Eucharist. After the corpse was given the final kiss of peace at the graveside, it was buried with its feet toward the rising sun. An agape might have followed immediately and there were services on various days after the death, as well as on the anniversary of the death. The Christian death was thus seen as a 'heavenly birthday'. There is no question that for the believers then, there was life after death which, according to Paul, is the reason for proclaiming the gospel.

The mediaeval ethos of the Christian burial took a different turn: that of fear. Burial came to be draped with the mediaeval imagination of hell and purgatory and the terrors of dying unprepared (Forrester et al. 1983:159). Pictures and painting of the last judgement, hell and its torments, were found everywhere. The late mediaeval drama often included hell's mouth, into which unrepentant sinners were dragged. Burials were usually in churchyards: the body was met at the corpse gate, carried into the church with psalms, and the Eucharist was celebrated. The dead person was granted absolution, incensed and sprinkled with holy water and the interment followed in the churchyard or beneath the church (White 1990:289). The 'day of wrath' chant was used, which focused on judgement and the possibility of judgement from the clear confidence of early Christians.

According to Forrester et al. (1983:60), the Reformation had to shake loose this attitude. White (1990:291 reasons that Luther deplored the mournful character of funerals and wanted to make them stronger expressions of hope. He condemned popish abominations such as vigils, masses for the dead, processions and purgatory on behalf of the dead. He was in favour of services that focused on the resurrection of the dead with comforting hymns of the forgiveness of sins, of rest, sleep, life and that of the resurrection of departed Christians. He made use of hymns, psalms, a sermon and a simple ceremony for burial rites. Calvin approved of sermons at burial but he, like Luther, did not provide a liturgy for Christian burial. White (1990:291) further states that the Reformed tradition tolerated a service of psalmody, scripture reading, sermon and prayer after the burial. Forrester et al. (1983) describe a typical burial: 
The corpse is reverently to be brought unto the grave, accompanied by the congregation, without any further ceremonies; which being buried, the minister, if he be present, and required, goes to the church, if it be not far off, and makes some comfortable exhortation to the people, touching death and resurrection.

(Forrester et al. 1983:159)

Practices like kneeling before the corpse and praying by or towards the corpse were viewed as being superstitious.

Funeral services in the nineteenth century also had their own trends. According to Pretorius (1998:188), death was generally believed to be a difficult process during which the dying required help to depart this life. Therefore there were specific rituals such as stopping all clocks in the house and covering the mirrors in the death-room. This was to prevent the spirit from becoming entrapped in its own reflection, or to prevent the deceased from taking along anyone who might see their picture in the mirror. The custom of taking out the corpse through the front door of a house with the feet first still exists among Africans today. The reason it is believed that the feet must exit first is that the spirit should not be able to find its way back home. Pretorius (1998:189) further states that the corpses of murderers, self-slayers, illegitimate children and sometimes even unbaptised children were buried facing the west. The rationale behind this was that they did not share in the salvation of Christ and therefore should not see His second coming.

\section{Conclusion on some basis theoretical principles}

- Burial was essential in the Old Testament and in the New Testament, and not to be buried was considered a curse.

- Mourning was permitted on the grounds that hope accompanied it.

- Death had to remind people of the joy and new life awaiting them in the New Jerusalem.

- The proclamation that accompanied funerals also had to be about the deceased's new life with God and not only about the comfort in the fact that they have lost a beloved.

- The funeral had to be a triumphant march to express the joy of the victory of the deceased.

- The funeral service calls upon hope and trust in the promises of God.

\section{METATHEORETICAL PERSPECTIVES FOR FUNERAL SERVICES}

\section{Results from a literature study and personal experience}

The concept one has of death usually determines what one does in the situations of death, and how the burial takes place. White (1990:130) states that the process of making sense of death is complicated further for twenty-first century people by the fact that they live in the midst of a death-denying culture. She maintains that these people routinely remove the dying from the living and place them in clinical settings. Kongocha (2000:40) states that one finds different customs surrounding the death and the funerals of a member of a particular family and clan. These different customs are based not only on the culture but also on the faith of the people. Liturgy teaches the meaning of death and gives the words, images and rituals by which people may speak honestly about death and dying, and it provides them with the tools to undertake the task of 'dying well'.

A number of rituals which should have been done away with among Christian members are still practised, even among church members. Many of these elements are evident in many funeral services (Tlhagale 1998:2-4). Some non-biblical examples are mentioned by Tlhagale (1998):
- Corpses are moved from a house feet-first, and never headfirst, so that they may not trace their way back to the house.

- Family members still shave their hair and undergo other rituals after the funeral. Some still bury certain artefacts with the deceased in the belief that these would be used in the near future of the deceased.

- In the case of a child who dies while having used medication, the bottles with medicine will be interred with the corpse or placed above the grave.

(Tlhagale 1998:2-4)

From this practice it is clear that some African people still have a great fear of death because it is an enemy that separates people from their loved ones. Many of the poems collectively called kodi ya malla (poems of lamentations) are indications of the African-Christian understanding of death. In many of these poems we hear words like these:

Death, you merciless one, you separate us from the ones we love. Oh, who would be there for me, the breadwinner is gone. If it were possible, I would have destroyed you death. I hate you...

In such instances, one may conclude that the gospel has little effect on people's understanding of death.

The practical situations of today show that burials have assumed a different pattern. Funerals are used for commercial purposes. Many people attend funerals to advertise the new clothes they have purchased. The family buys expensive coffins and very costly tombstones in order to impress those who attend the service. Expensive meals are prepared for the funeral-goers. The result of this is that many families go without food after the burial, as they are left to pay the accrued funereal debts, and the surviving children suffer the consequences. The deceased are not always buried immediately: at times there is a two-week delay to accommodate family members that work far away. The family members that are nearby are often unable to make final decisions, since they have to wait for the other members. The longer the corpse remains in the mortuary, the higher the cost. This escalates the cost of funeral services and the unfortunate part is that some of these family members arrive without any financial support for the family that has arranged the funeral.

In the case of death, the core belief that remains is that the deceased has to be buried properly, or that spirit will not find rest. This goes hand in hand with mourning. African people mourn a great deal when someone dies. The concept of 'mourning' has a very long history, and congregations also have their own way of comforting the bereaved. It has become tradition among a number of churches to have comforting services during the last week before burial, as well as on the last night before the interment. These comforting services are usually short, depending on the place and on the different congregations. There is usually a day for the youth to attend, a day for the elders and church members to attend, and a day for women to attend, in most of the denominations. The service on the last night before the burial takes the longest: in some instances it ends at midnight, and in some it is like the shorter, comforting services. In other cases it lasts until morning.

Attention should be paid to the different forms of these comforting services. It should be noted that no written documentation of these has yet occurred. The youth visit the place of the deceased predominantly on Tuesdays or Wednesdays. They are from different denominations. If circumstances allow, they will meet together; if not, they will comfort the bereaved families at different times during the week. The women's organisations meet on Thursdays and immediately after their meeting, they will also go to the place of the bereaved to bring a message of hope and comfort the family. These groups would usually conduct a prayer, scripture reading and a message of hope from one or two members, depending on the time available, and the visit involves singing. The other church members would usually visit on the days when the youth and women's organisations are not in attendance. Some 
of the church members available will talk to the bereaved and give them words of comfort.

With regard to the night vigil, it has been indicated that its origins lie in the fear that people developed during the mediaeval period and the seventeenth century. People were on their guard so that the deceased should not return or awake while they were preparing for the burial. It appears to have assumed a Christian character because of the prayers, scripture readings and singing. Today, there are many comforting words that have a strengthening effect on the heart of the people present. Kongocha (2000:46) states that the tradition of night vigils began in the early Church, the rite of funerals began with a viaticum and included a nightwatch, during which the Christian community celebrated the Word of God and prayed for the dead brother or sister. Kurpershoek (1996:254) states that the night vigil has a heathen origin. It was influenced by the fact that people believed the spirit of the departed would leave the body and hover near it. For this to take place, protection through a vigil was called for. This being the case, practices of this kind have to be abolished among the Reformed Churches of African origin, unless proper supervision by the church leadership is exercised throughout the course of the week. This means that the Church would have to be present and give direction daily to make this a Christian praxis. The other main difficulty with this process is that in many cases, gatherings today lack proper liturgical planning. Therefore the church would need to step in and help shape a form of celebration that fits within the culture and the belief, as is the purpose of liturgy.

However, there are some important issues to examine in order to assess the relevance of night vigils today. Night vigils have lost their essence to a very large extent. While previously all people gathered in a house, people now gather outside in tents. Unfortunately, few of the bereaved attend these night vigils. Church members usually comfort themselves. The situation is not pleasing to these members since they do not realy succeed in their goal of comforting the bereaved. Their visit turns into formality. Hence it would rather be advisable to have a comforting service that would last for an hour or two at most. The situation now is such that mourners have adopted a practice that is referred to as 'after tears', where friends of the deceased gather for drinks after the burial. This is their way of saying that the departed friend has completed his earthly role and that those who remain should forget about him and continue with life, making the best of it while they can. Their reason is not to comfort the bereaved to place their hope and trust in the Lord who overcame death. Instead, it is centred more on burying the persons to get them out of the way and to continue with life.

The burial ceremony that is so strongly marked by personal life relationships, expectations and religious observations brings together people for reasons different than that of common faith. It is common practice in most places for people to attend funeral services not because they know the deceased, but because of how they would benefit from attending. Firstly, they aim to be seen so that when they die, they merit a big funeral. Secondly, many inquire about the animals slaughtered: the more meat available for the funereal meal, the more people can be expected to attend. The richer and more well-known the deceased or the family of the deceased, the higher the number of funeral-goers expected. This, in most instances, truly has little to do with sharing common interests and coming to comfort the bereaved. Believers as well as non-believers, friends as well as enemies, can be counted among the attendants. Unfortunately, funerals of lesser known or impoverished people are poorly attended, especially in the absence of meat at the burial service meal.

African people want to know where their relatives are buried so that they can visit them in time of need or consultation. If a family member is not buried at home, the African would pursue all possible means to get their deceased family member buried next to that of the other family members. Moreover one's life here in the visible world determines what kind of an ancestor one would be in the invisible world. To become a mediator also depends upon the age and the status the deceased occupied while still in the visible world. Many burial customs are such that a proper burial is regarded as important in order to evade any misfortune that might arise from an improper burial service.

The fact that African people view death with fear is because of their opinion about death. It is difficult for most of the African people to accept the concept of resurrection. They feel secure in the knowledge that the deceased are just in a different world of spiritual beings. For them, it is a complete separation with no hope of meeting again in the human lifetime, and then perhaps only in the world of the spirit beings. The African churches invest a great deal of time in teaching people about the resurrection and the new life in Jesus Christ. There are night vigils and daily evening comforting services in the last week before the burial. However, people still fail to comprehend the mystery of the resurrection, and still espouse their cultural beliefs. In a recent youth conference in Zamdela (held on 18-20 June 2005) questions were asked on how it could be guaranteed that nothing would happen to a Christian who does not follow specific cultural demands. If the family members of a deceased person are not purified after some time, it is believed that they will be beset by bad luck in life. Despite the fact that these people are confessional Christians, they have a great fear of the ancestors, even greater than their fear of God. They do not have a problem following Christ as long as He does not interfere in their relationship with the ancestors.

\section{Empirical results on funeral services}

Under the rubric of the empirical studies, some qualitative research was carried out: new information was gathered in the form of interviews four congregations were visited, and five people from different age and gender levels from each congregation were interviewed. The criteria for the selection of the congregation were based on the level of the enculturation that took place during the last few years. The first question dealt with the issue of burial and why people are buried.

The positive results for the empirical research on the reason for burial were'2: Jesus himself was buried and this is an indication that humans have to be buried; burial is like sowing a seed (it indicates hope for resurrection); burial is very traditional (human beings cannot be thrown away like dogs).

Negative results of the empirical research about the reason for burials: burial is simply a choice - one can even be burned; people can simply just be left to decompose; burial is there for reconciliation among the living and the dead.

The second question dealt with the comfort one derives from burial. The positive results of the empirical research on the reason for burial were ${ }^{3}$ : burying a deceased person is comforting because it presents an opportunity to hear the Word and it brings people together; burying a deceased person comforts because it gives peace of mind to the bereaved, and because it seals contact/communication between the living and the dead.

Negative results of the empirical research about the comfort from burials: comfort is received when the deceased is buried properly; comfort is received when one knows that he will be able clean the place of burial because he knows where the place is.

\footnotetext{
2.The full report on the answers to the specific question: 'Why should people be buried?' is available from the author.

3.The full report on the answers to the specific question: 'What comfort does one get from burying a deceased?' is available from the author.
} 


\section{Conclusion on some metatheoretical perspectives}

A proper funeral service or burial to the African is a sign of respect to the deceased. It determines partly what kind of ancestor the deceased would become, but it also shows what relationship the deceased had with the people he or she lived with. Moreover, it functions as a plea on the part of the family to the ancestral spirit to protect them. The concept of ancestral veneration leaves no room for the resurrection. In this regard, it is believed the spirit lives on to eternity.

Funeral services have different customs based not only on the culture, but also on the faith of the people. Funeral services are strongly marked by personal life relationships, expectations and religious observations that bring people together, despite the fact that it might not be in common faith as a community of believers.

Liturgy in death situations teaches people the meaning of death and it gives them the words, images and rituals with which to speak honestly about death and dying. Funeral services provide them with the tools to undertake the task of 'dying well'.

Funeral services have largely become commercialised as well as secularised.

\section{PRACTICE THEORETICAL GUIDELINES FOR FUNERAL SERVICES \\ Practice theoretical guidelines}

Funeral services should always focus on hope for the resurrection of the body. They should give comfort to the bereaved and to the church that it pleased God to give His children rest from earthly responsibilities and hardships.The liturgy of the funeral service - through its words, symbols and images - should help the bereaved and the church to have an experience of the heavenly joy that waits after the resurrection.The proclamation of the Word should maintain or even improve their focus on the victory of Christ over death and His resurrection.During funeral services people's focus on ancestral veneration should be diverted so that God's word should have the final say.

\section{Practical application focusing on correct teaching}

New members in the Reformed Churches of African origin are simply taught a few basics or nothing at all about the Reformed faith: they learn nothing or very little of what it means to be a true Christian. It is not surprising to see many Reformed Churches of African origin growing in number, but not really in quality and in faith. Most of these African people hold on strongly to their culture and tradition. There should be more emphasis on the real issues affecting the African people directly. African people have their own burning spiritual issues that are affecting their relationship with God to a large degree. These issues need immediate, serious attention; Christian worship versus ancestral worship, Christian faith versus African faith and other religions including the issues of sects and indigenous churches, and Christian death versus African death and related matters.

The teachings should be placed within context: it will not make sense simply to teach about the good of the Christian faith without, at the same time, being apologetic and polemical. One has to teach the doctrine, defend the faith and attack wrong teachings. African people can be won in this way for the Lord. In fact, African people truly know how to bury their beloved ones, giving the world's respect to the deceased. Even poor families try to give a proper burial to their loved ones. The problem encountered is not that of burial but the beliefs that accompany themlike the fact that many elderly people are buried with expensive new blankets in the belief that they will need them beyond the grave. Through correct teaching, these problems would no longer be problematic because people will understand that there is no life in the grave, as the Bible teaches. Hence there is no cold or heat, trouble, pain or sickness in the grave.

If the teaching about death were correct, there would be no need for ditlhapiso (cleansing rituals) after the burial for purification and ho rola thapo (ritual to end the mourning process) after a month or two because Jesus Christ overcame death and has conquered it. The powers of darkness have no effect and strength over His children. It is evident that it is not enough simply to concentrate on issues of death during a situation of death. The teaching should be there at the right time when people can concentrate fully and comprehend it. It is also important to give individual attention to the bereaved.

It is good that the church sets a specific time for visiting bereaved families. Yet it is more important to make special appointments with individuals to understand what impact death has had on them individually. Many of these people suffer terrible emotional pain. When it happens that another family member passes away, they start to develop hatred and anger against God.

If the church focuses on the individual problems, the true meaning of burial would be comprehended. Death would not be a threat to members any longer, but they would look forward to dying like Paul, knowing that it would be of profit to them (Phlp 1:21). Burial would be like planting a seed that will decompose in order to give birth to new growth in Jesus Christ upon the resurrection. The joy experienced in heaven would be experienced here on earth for the person who has reached the last mile of the way. Christians would see funeral services as an invitation summoning them to rejoice in unison in the triumph of the Saviour over death and in the expectation of the resurrection.

\section{PROPOSED GUIDELINES FOR THE LITURGY OF THE FUNERAL SERVICE}

The aim is to offer guidelines on how funeral services may be conducted so that they can help focus on the resurrection of the body and the new life waiting ahead, and not on ancestral veneration. These guidelines comprise a liturgy for mourning service, a funeral service, as well as a graveside service.

\section{Liturgy of the mourning service (night vigil)}

It has been indicated that African people, including Reformed members, are partial to attending night vigils before the day of the burial. What is important is the fact that night vigils provide opportunities to help the family deal with the death, although the word 'night vigil' might have a negative connotation for some people. There is some time to focus on the life of the person, to be reminded of what an asset that person has been to the community and to the family. This supports the family in their farewell to the departed, and in their knowledge that God has made good use of this person. This is an opportunity for the community and the church to express their understanding of the family's pain, to share in it, and to cherish reminiscing about the virtues of the deceased.

It is important to give liturgical order to this ritual and to distinguish clearly between what is referred to as words of encouragement and words of preaching. Perhaps one should refer to a 'memorial service' rather than a night vigil. God can strengthen his children by making use of different people other than the minister. The different gifts of the Spirit to the church should not be limited in times of death. A mere hymn sung by a congregation member can have a very great impact on the lives of the bereaved. One should not underestimate what God 
can accomplish through other people, 'motho ke motho ka batho ba bang', (a person is a person through other people). For order to exist, there should be one who could lead the whole service, preferably a member of the Church council, who would understand what is expected of the Reformed Churches. The liturgy itself should have divisions, starting with the Word of God, followed by words of encouragement from the church members, from family members and from friends. This should be followed by encouragement through singing.

Liturgy of funeral service

The liturgy of the funeral service may follow this pattern:

1. Opening Scripture: Psalm 91 in its entirety

2. Opening hymn

3. The family of the deceased normally chooses hymns

4. Opening prayer

5. Welcome and statement of purpose of service

6. Brief acknowledgement of relatives and friends of deceased: The following could be expressed:

We are going to miss (name of deceased person). As individuals, we think there is no more difficult a time than this to express our true feelings. Some of us would like to bring tribute to him/her on this occasion.

7. Tributes to deceased: Here follow tributes to the deceased that may be read, or brought by those who wish to do so personally, or they may be read by the liturgist on behalf of the family and friends of the deceased.

8. Bridge statement between tributes and Scripture readings

9. Independent Scripture reading(s): These may be read by the minister, or better still, by members of the family or congregation: 2 Corinthians 4:16-15:8, Isaiah 41:10,13; Psalm 23:1-6; Psalm 145:18-19; 46:1;

10. Hymn

11. Scripture reading and message: The message should be brief, but clear, and should help people focus on the resurrected Jesus Christ.

12. Prayer

13. Bridge statement between memorial service and graveside ceremony: This is normally a statement by the representative of the funeral directors, and gives instructions to the attendees with regard to procedure to and at the graveside.

\section{Graveside service}

1. Opening prayer

2. Suitable hymn

3. Scripture reading: Relevant Scripture portions may be read here with a short sermon or words of encouragement to the bereaved.

4. Interment: These words may be said before the interment:

In the light of these promises of God in His Word, and because it has pleased the Lord in His divine wisdom and purpose to take from our midst one whom we have loved, we commit the body of (name of deceased person) to his/her final resting place to await the fulfilment of these marvellous and comforting promises of the Bible.
While the body descends, all together may make their public confession of their infallible faith. The 'Our Father' can also be said immediately after the confession of faith.

5. Closing of the grave: African people are very hesitant to leave the grave if it has not yet been covered. While people are waiting for the grave to be covered, suitable hymns or psalms may be sung.

6. Blessing/send-away greeting: To leave the gravesite with greetings from the Lord truly encourages the bereaved, as they will have received the assurance that indeed God is present and is with them.

7. Words of thanks: It has become the custom for the family of the deceased to summon one of the family members to thank people for their ministry and care of the deceased in time of sickness, and for their ministry and support in the funeral service itself.

8. Invitation to fellowship at a previously set venue

If God were not present during a funeral service, there would surely be no true comfort. People would grieve like those without hope for resurrection. Death would be a very great loss to them. Ubuntu (humanity) is needful in such moments. The bereaved need support and care, and this is where African people should consistently express their support for and care of them.

\section{REFERENCES}

Achtemeier, P.J. (ed.), 1985, Harper's Bible dictionary, CD-ROM, Harper \& Row, San Francisco.

Easton, M., [1897] 1996, Easton's Bible dictionary, CD-ROM, Logos Research Systems, Oak Harbor, WA.

Forrester, D., McDonald, J.I.H \& Tellini, G., 1983. Encounter with God. Clark, Edinburgh.

Kongocha, C., 2000. 'The funeral rites and inculturation', Spearhead, 40-47.

Kurpershoek, W. L., 1996, 'Afrika-sinkretisme - gereformeerde prediking en pastoraat' [African syncretism - Reformed preaching and pastorate], In die Skriflig, 30(2), 241-262.

Macleod, D., 1966, Presbyterian worship, John Knox Press, Richmond.

Orion, P.E., 1966, The funeral vestige or value? Abingdon Press, New York

Pfeiffer, C.F., 1975, Wycliffe Bible encyclopedia, CD-ROM, Moody Press, Chicago.

Pretorius, E.E., 1998, 'Dood en begrafnis in die negentiende eeu' [Death and burial in the nineteenth century], Studia Historicae Ecclesiasticae 24, 188-205.

Rowell, G., 1977, The liturgy of Christian burial: An introductory survey of the historical development of Christian burial rites, SPCK, London.

Tlhagale, O.M.I., 1998, 'Enculturation: Bringing the African culture into the Church', Journal of Black Theology in South Africa 12(2), 1-18.

White, J.F., 1990, Introduction to Christian worship John Knox Press, Louisville. 